\title{
Artelogie
}

Recherche sur les arts, le patrimoine et la littérature de l'Amérique latine

$5 \mid 2013$

Femmes créatrices en Amérique latine : le défi de synthétiser sans singulariser

\section{Feminist Disruptions in Mexican Art, 1975 - 1987}

\section{Andrea Giunta}

Translator. Tamara Stuby

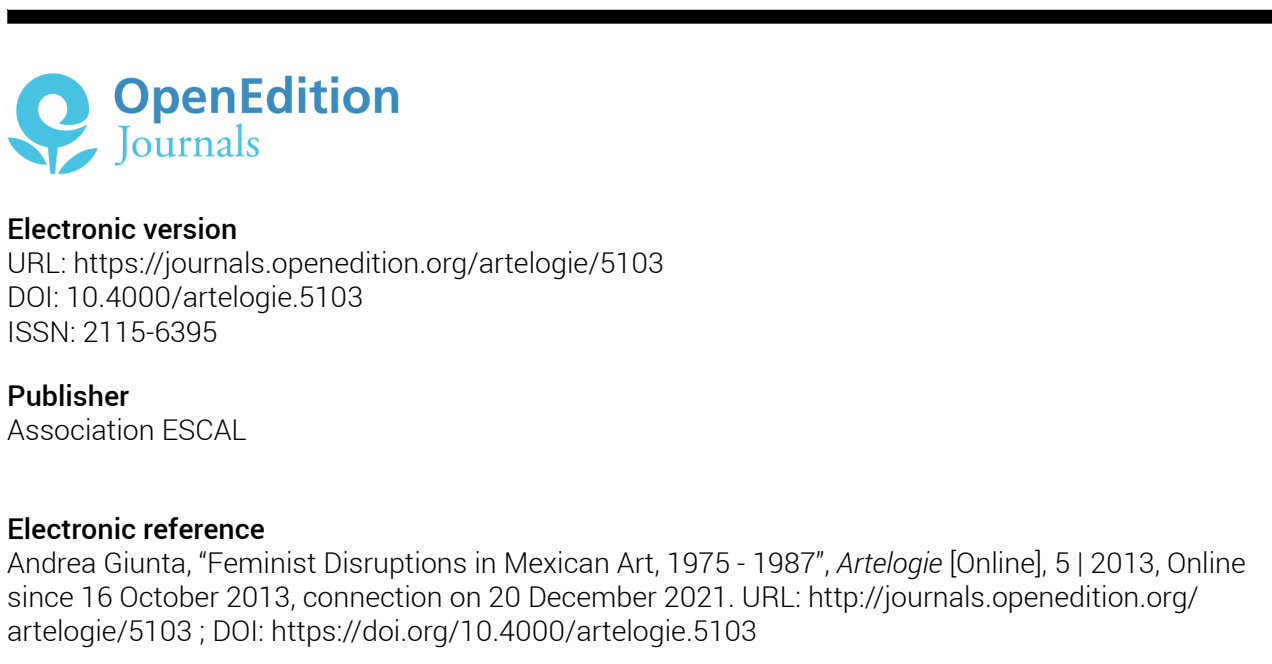

This text was automatically generated on 20 December 2021.

Association ESCAL 


\title{
Feminist Disruptions in Mexican Art, 1975 - 1987
}

\author{
Andrea Giunta
}

Translation : Tamara Stuby

\section{EDITOR'S NOTE}

List of illustrations in Artelogie Expo Revue

\section{Introduction}

1 The International Woman's Year (Año Internacional de la Mujer) was celebrated in 1975 in Mexico City with the organization of a first global conference. The event was linked with the strategy of Luis Echeverría Álvarez' government to improve the country's international status in terms of human rights, which had been damaged due to the Taltelolco massacre in 1968. In connection with the event, several exhibitions and activities were held that revised women's place in Mexican art. The Palacio de Bellas Artes presented La mujer en la plástica (Women in the Visual Arts) and Pintoras $y$ escultoras de México (Women Painters and Sculptors of Mexico) was held at the Poliforum Cultural Siqueiros. However, the most significant exhibition was the one organized by the Museo de Arte Moderno, La mujer como creadora y tema del arte (Women as Creators and Theme in Art), in which large part of the paintings were, paradoxically, authored by men. ${ }^{1}$ In relation to this revision, Carla Stellweg, founder and editor of Artes Visuales ${ }^{2}$ magazine, published by said museum, organized a seminar whose results were published the following year, establishing a map of positions that would affect future developments in feminism in the arts in Mexico. The ideas advanced there were linked to those being proposed on the international arts scene, with which Mexico enjoyed a relationship that was unequalled by any other art scene in Latin America. Although a chronology and list of names of the main protagonists of feminist 
interventions have been recovered (MAYER, 2004 and BARBOSA, 2008) and a good compilation and translation of historiographic interventions to date regarding the history of art and feminism has been edited in Mexico (CORDERO REIMAN and SAENZ, 2007), no reading has been carried out as yet of the intervention achieved by a group of radical works that made the configuration of the aforementioned scene possible.

Between 1975 and 1987, diverse works and exhibitions established different inflections in the debate on feminism in the arts in Mexico. This article proposes to undertake the analysis of a group of interventions that range from collage to video and performance as its starting point, works that bring to bear a specific point of view regarding issues handled by Mexican women artists in conceptual, experimental and political ways. From this perspective, works by Lourdes Grobet, Hora y media (Hour and a Half), 1975; or Mónica Mayer, El tendedero (The Clothesline); Magali Lara, Ventanas (Windows); Pola Weiss, Ciudad, mujer, ciudad (City, Woman, City), all three shown at the 1977-78 Salón nuevas tendencias; Ana Victoria Jiménez' photographic essays produced between 1978 and the early '80s; the transnational group experience carried out in response to Mónica Mayer's initiative, Translations: An International Dialogue of Women Artists, in 1979-80; or the television performance she carried out jointly with Maris Bustamante in Madre por un día (Mother for a Day), presented in Guillermo Ochoa's program in 1987 will all be analyzed. Our aim is to restore the disruptive force of the images and group experiences that fertilized the exceptional nature of this moment in Mexican art in Latin American art. Displacing this analysis from a chronological structure toward these works' underlying strategies will allow us to develop this essay's central hypothesis. This sustains that the substitutional perspective that provided the guidelines for the relationship between the second wave of feminism during the sixties and seventies, critique enunciated from the post-feminism standpoint and the introduction of gender and queer theory perspectives have generated an interpretative model that, in the guise of reading how politics of the body should be approached in a 'correct' way, have erased the historical texture in which critical positions and images configured a terrain of problems and perspectives that do not necessarily conform to the same assumptions from which they emerged. This text upholds that in some cases, these works introduced disobedient corporalities that have been overwritten by the framework of the feminism that has finally penned them in. From this viewpoint, our aim is to contribute to an exercise in rereading them that will unleash new potential for intervention in a body of images immobilized by classifications.

\section{Women/art/femininity}

3 The seminar organized by Carla Stellweg in 1975 situated discourses coming from different disciplines on the same table (JACOME, 2012). ${ }^{3}$ The questions that circulated among participants there took Linda Nochlin's article, "Why Have There Been No Great Women Artists?" published in ArtNews in 1971 as their point of departure. Stellweg linked the revision of women's place in Mexican art to notions such as social class, capitalism, and minorities (STELLWEG, 1976: p.5). She also asked whether or not characteristics of language inherent to feminine expression might exist. The succession of presentations built up a texture of discourse that gradually gained ground on a group of considerations regarding the specificity of the feminine and the configurations of cultural power that excluded women from histories of art. The 
following is a synthesis of several of the positions that were presented at said encounter.

With the advent of erudite culture, women's creative activity had undergone an excision, where the place that popular, folk and collective art had occupied was lost. This observation, introduced by anthropologist María Eugenia Vargas de Stavenhagen, lent meaning to contemporary art production such as that by Marta Palau (one of whose immense tapestries appeared in reproduction in the magazine), which admitted weaving as a legitimate technique in the terrain of high art. In this way, a technique that had been relegated as minor by the exclusive classifications that configured artistic value was recovered.

5 From the standpoint of legal discourse, lawyer Sara Chazán asked why so few women appeared in books on Mexican art (she referred to Justino Fernandez' history of art ${ }^{4}$ ), if Mexican legislation had guaranteed them equal rights under the law to full selfdevelopment since the 1917 Constitution and the Ley de Relaciones Familiares (Law of Family Relations) had been passed. However, the transformation of social conscience was not determined by laws.

6 North American feminist poet Margaret Randall, in turn, subsumed the transformation of women's place within a larger social revolution. In Mexican society, women's insertion in the job market set the parameters for said place, since they represented $20 \%$ of the labor force, situated in the services sector (nannies, waitresses and cleaning women subjected to oppression and exploitation). In order for the place of women to be changed, society had to be transformed. The Cuban revolution was the point of political reference that oriented her analysis. There, women could be reading instructors, doctors, engineers, farmers, architects, teachers, scientists, administrators, athletes, soldiers or artists. Their children were born with access to a hospital system, schools were open to all sectors of society, and public schools did not pertain to an elite. Blacks and the poor could develop their talents. Randall's text was written and dated in Havana. $^{5}$

7 Art historian Ida Rodríguez Prampolini, on the other hand, sustained that women had not made a significant contribution to art because their criteria followed the norms of a patriarchal and capitalist society. For women relegated to the home, art was an adornment, not a profession. In her view, changing this state of affairs also implied transforming society.

8 Psychologist and art historian Teresa del Conde introduced gender perspectives. She held that not all human beings who are not men correspond to the female gender, nor do all of those who are not women correspond to the male gender. The biological definition of woman as having a uterus and hormones did not correspond to a definition of the feminine. What she conceived of as feminine was tied to a number of determining factors: cultural inheritance, education, social class and historical period. Only in the $19^{\text {th }}$ Century did women begin to "un-feminize themselves" and to acquire visibility. If it had taken such a long time for this to happen, she concluded, it was logical that the percentage of women visible in the art world was still lower than that of men.

9 Alaide Foppa, feminist critic, political activist and art historian from Guatemala residing in Mexico, also stated that women began to become more visible in an art world with values that had been established by men. As a sector that had been 
dominated and discriminated against, women artists did not look to produce women's art, but art that would resemble that of their dominators. She found it difficult to identify feminine traits in their language, though it might be possible to establish certain themes that did tend to recur.

For Helen Escobedo, sculptor and Director of the Museo de Ciencias y Arte, Universidad Nacional Autónoma de México, the level of visibility achieved by women's work was a matter in their own hands, in their capacity to organize the dynamics of the family in order to be able to carry out different roles successfully.

Art critic Barta Taraceno sustained that art was a human expression, not a masculine one. It was not defined by sex but by talent, and what women lacked was not talent but access to the media. To the extent that this access improved, so would women's visibility.

The sum of the papers presented during the seminar provides an indication of the map of different positions in the debate on women's place in Mexican art. Issues related to how women were represented were introduced; political agendas were pulled taut by the insertion of questions regarding priorities for this change: should women's place in society be changed, or was it society as a whole that had to change by way of political revolution? Notions of class and race were introduced as structures that subordinated the priority of the question of women's representation; the possibility of considering the feminine in relation to a specific language was proposed; the tension between the notion of pure art and its impugnation in light of the criteria employed by society's patriarchal structure in establishing its values was approached; the masculine and the feminine were taken aside from the separation between man and woman to introduce the idea of gender as a cultural construct; it was proposed that the question regarding the feminine was one regarding one's own identity. In this way, a map of alternatives was elaborated that made it clear that although all who had spoken were women, with a common point of consensus-their scarce representation in the history of art in general and that of Mexico in particular-as their point of departure, their positions varied widely.

When the results of this seminar were published in issue number 9 of Artes Visuales magazine in 1976, interviews with Judy Chicago and Arlene Raven were included; both defined the question on the basis of their practices and interventions in the art field. Chicago proposed subverting dominant aesthetic values and introducing others that she enunciated as a woman, as part of non-dominant culture. When asked about the difference between her form of expression and that of a male artist she explained:

I make a shap and that shape is soft and vulnerable and inviting and asserts, by implication that it is good to be soft and vulnerable and inviting. That challenges the social values that teach that personal exposure means weakness. My images speak of vulnerability that is wedded to strength, not weakness." (CHICAGO, 1976; p. 62). In her view, transforming the parameters of power did not imply sustaining a new relationship with power. As a feminist, she aspired to a world where the domination of some by others would not be an issue.

Art historian Arlene Raven also held that art's values had been established by dominant sectors. As such, when non-dominant forms of expression emerged, their agenda had to be articulated. She did not hesitate to recognize feminine specificities in forms and iconographies. As an art historian, she considered the historic nature of these traits 
and their processes of transformation. Although she considered that phallic or vaginal forms were employed by both men and women, she confirmed that during the past three years, the appearance of themes tied to women's experiences (such as the conjugal bed, rape, tampons or the color pink) had become more evident. Based on the emergence of these themes, she speaks of the existence of a feminist art and the need for a history of feminist art capable of interpreting it.

The last section of the magazine's dossier featured an article by Lucy Lippard. In it, she held that exhibitions were an efficient way to transform the system of power in art rapidly. From this perspective, she wrote texts for the catalogs of exhibitions such as Diez artistas que también son mujeres (Ten Artists Who are Also Women, at the Kenan Art Center, Lockport, N.Y and the Michael C. Rockefeller Art Center, Fredonia, N.Y, 1973) or Mujeres eligen mujeres (Women ChoseWomen, at the Women in the Arts Cultural Center, New York, 1973). These exhibitions were necessary because until that time, there were still very few women in commercial galleries and large museums did not exhibit their works. Above all, they were not present in spaces in New York, where they had been particularly discriminated against under the guise of selective quality. Not even women themselves knew about other women's work. This panorama was quickly modified, accelerated by the heat of meetings, demonstrations and groups to raise awareness. In the latter case, women realized that in some sort of negotiation with the recognition system, they had divided their work into two areas: a masculine art for the mainstream, and another, private art related to entertainment and employing feminine techniques. Lippard met an artist who made hard edge color field abstract works for the professional world of art, while in her free time she would take nude photographs of her friends with wallpaper backgrounds. The private style contrasted with the public one. Lippard herself situated her fictional texts among her leisure activities. This "closet art" (vulnerable, private, "minor") touched on feminine experiences that did not come out into the art world. She sustained the need to show this art and to exhibit it with an awareness of the critiques that would disqualify it:

Whenever there is a women's show, or a Black artists show, or any similarly "segregated" event, objections are raised on the basis that art is art and has no sex, no color. That's all very well, but artists do, and there has been considerable discrimination against artists of a certain sex and a certain color. A woman's show is no more arbitrary a manner of bringing together a group of art works than a show of Czechoslovakian Art Since 1945 or Artists Under 35. (LIPPARD, 1976; p. 64).

Lippard confirms that in her own activity as a critic, she had dedicated more time to analyzing work by men than by women. In spite of being familiar with the anonymous role of being an artist's wife (she was married to Robert Ryman) who would prepare coffee and receive guests, she was unaware of works by women who were neglected in bedrooms and kitchens. In this sense, in spite of an initial resistance to the idea, she was able to confirm, as Judy Chicago and Miriam Schapiro had proposed, that specific marks did exist:

... a uniform density, or overall texture, often sensuously tactile and repetitive or detailed to the point of obsession; the preponderance of circular forms, central focus, inner space (sometimes contradicting the first aspect); a ubiquitous linear "bag" or parabolic form that turns in on itself; layers, or strata, or veils; an indefinable looseness or flexibility of handling; windows; autobiographical content; animals; a certain kind of fragmentation; a new fondness for the pinks and pastels and ephemeral cloud colors that used to be tabu unless a woman wanted to be accused of making "feminine" art. (LIPPARD, 1976; p. 65). 
Chicago and other feminists understood that the awareness of the existence of a specific language formed part of the reconciliation process with themselves as women. Along with sexuality, it focused on other aspects of their condition as women, linked to sewing or to the kitchen, for example. Nevertheless, institutional structures did not yet reflect the appearance of these works. Only five women artists were included in the Whitney's annual show in 1970, out of a total of one hundred fifty artists selected. The organization of feminist programs on university campuses represented one option for transforming this state of affairs. The dossier mentioned The Woman's Space, the WAR group: Women Artists in Revolution, the feminist art program in California, the formation of a library, slide bank and registry of women artists and the creation of the Feminist Art Journal, edited in New York by Cindy Nemster. All this information intervened, as we shall see, in the direction taken by the feminist art scene in Mexico.

\section{Hour and a Half}

19 The three 1975 exhibitions were not the only ones to handle the theme of women. That year, in the same forest at Chapultepec where Stellweg developed her seminar, Lourdes Grobet carried out a photo performance at the Casa del Lago, a cultural center created in 1959 by poet and writer Juan José Arreola as part of the Universidad Nacional Autónoma de México (UNAM). ${ }^{6}$

Grobet's action brought together three photographs taken by Marcos Kurtzycz that recorded her at the moment she passed, clothed, through a frame on which a sheet of metallic paper was stretched.

Lourdes Grobet, Hora y media, photo-performance

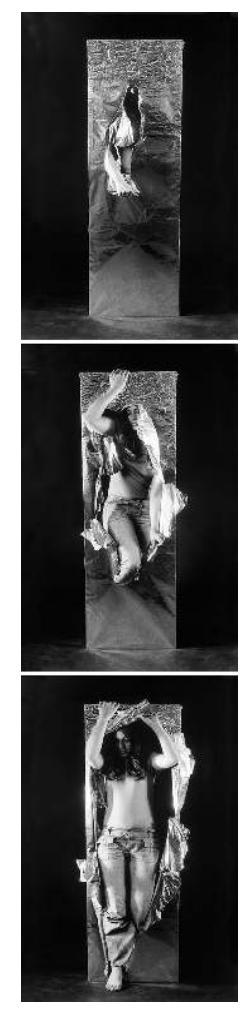

Casa del Lago, México D. F., 1975

Artelogie, 5 | 2013 
21 turned into a darkroom, but without fixer. Once printed, Grobet hung them on the wall and turned on the light, and the photos disappeared. Although this exhibition took place at the same time that revisions of women in Mexican art were multiplying, it went by unnoticed. However, seen in the context of the explosion on the level of discourse on women that was taking place at the time, these images take on significance as an intervention, in terms of what they represent (the artist, with her own body which generates the work) as much as for the devices they introduced. The latter allowed her to establish a scenario from which to read something that is in transition, a discourse on limits: those of photography and those that apply to her own body's condition of being visible.

At the same time, the image activated relevant moments of the post-War avant garde. It was, in a sense, an iconographical inversion of Saburo Murakami's (from the Gutai group) performance in 1956. Now it was she, a woman artist, who converted her body into an agent of action. It was an action where she made the record of it disappear as part of the work's planned intervention. Gorbet made the archive of an action visible and the timeline of the action itself turned its contemplation back into performance again. It was an image that disappeared, a presence-hers, that of a woman in Mexican art-that existed, but without artistic status. In this sense it is worthwhile to recall that in the introduction to a catalog from the Museo de Arte Moderno, Fernando Gamboa had explained that women's participation in Mexican art was recent because they had expressed themselves in "minor arts" such as ceramics, weaving and embroidery more than in the "fine arts". For him, it was this "late development of their sensitivity" that had determined their limitations (BARBOSA, 2008; p. 33).

Grobet produced (and repeated) the gestures of an avant garde artist but submerged in evanescence. This represented the erasure of an important step in the technical history of photography, the possibility of fixing the image, thus allowing it to transcend time. With this device, based on a technical process, Grobet activated and enacted the issue emerging as a problem at that time of how to represent a body. The second record, which forms part of the artist's archive today (the photograph of the photograph that disappears), allows us to reconstruct the way in which this image intervened, articulating the sensitive interstices of a debate that remained diffuse: the debate focused on women's intervention in the field of artistic images represented by a repertoire of languages and creative processes as well as the transformation of legitimizing spaces. The image restores the field of unstable positions that the participants of the symposium at the Museo de Arte Moderno had also developed, but in a visual key.

\section{Salón 77-78 Nuevas Tendencias}

It is likely that Magali Lara may have found the starting point for her Ventanas (Windows) series in the compendium of themes and the summary of formal devices listed by Lippard. The effect produced by the publication of the issue of Artes Visuales, together with information along similar lines distributed by feminist activists mobilized new forms of consciousness. These themes and issues became visible in the Salón 77-78 Nuevas Tendencias, held that year at the Museo de Arte Moderno. 
Documentation in Magali Lara's archive reveals that in the moments prior to organizing the Salón, an initiative began in 1976 at the hands of the sculptor Sebastián which artists joined in on without taking a unified political or aesthetic stance (hence the name "independents"). From that platform, they convened artists for the Salón 77-78, consolidated on the basis of requirements such as youth, interest in experimentation with language and the theme of Mexico City.

In this Salón, Magali Lara's works Ventanas, an installation by Mónica Mayer, El tendedero and the videos Ciudad-Mujer-Ciudad and Somos mujeres (We Are Women) by Pola Weiss were all shown together (MAYER, 2004; pp. 17-18). One posed questions regarding intimacy and the biographical, another presented the results of a survey carried out with women from Mexico City and the third showed the body of a nude woman in a crude, direct form with overlapping images of Mexico City.

27 As Mónica Mayer pointed out, the frames and the order in which Magali Lara presented her 78 drawings at the Salón Nuevas Tendencias made them look like a building (MAYER, 2004; p. 18). It was a wall of intimacy.

Magali Lara, Ventanas, collage with photocopies and pastel, $1977825 \times 22.5 \mathrm{~cm}$

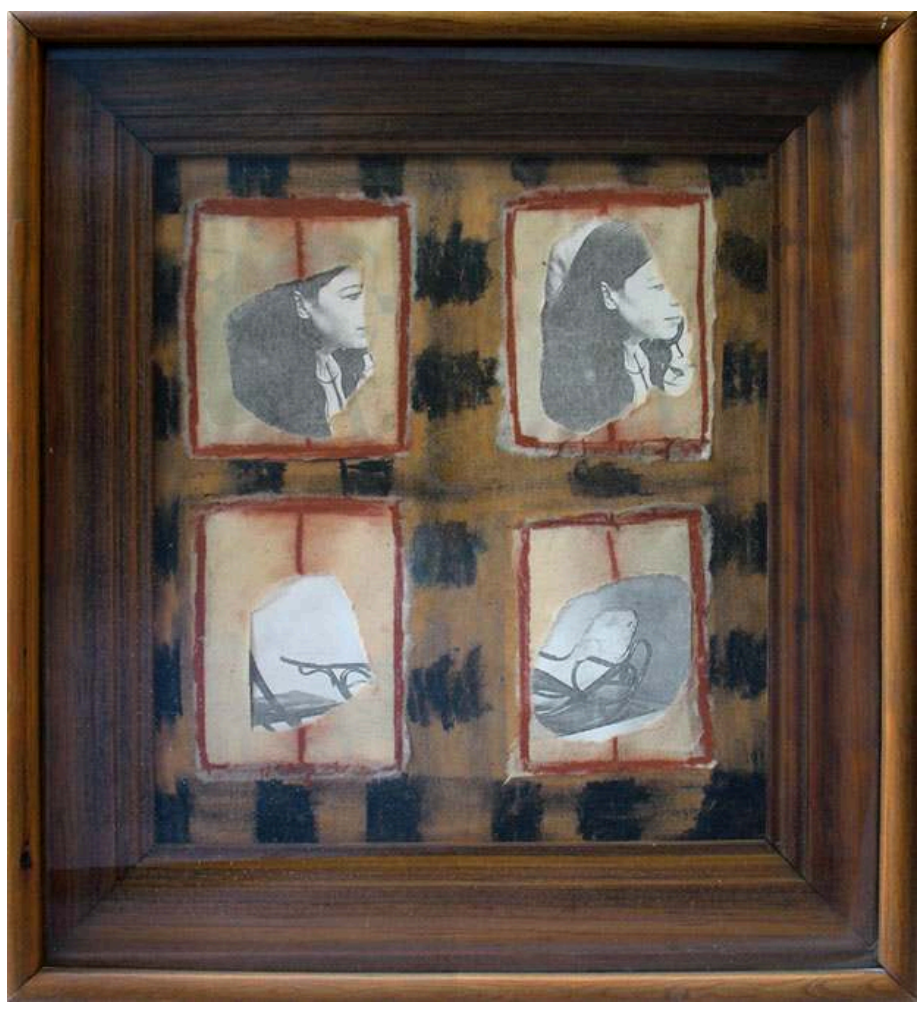

In Ventanas, elements linked to her subjectivity were deconstructed within each frame. Lara called upon drawing, collage, texts and slides in order to take on a task of intimate, emotional biographical research. Although she maintained that she was not a feminist, from 1977 onward she would investigate how to introduce feminine themes and perspectives in art. One example was the series she developed dealing with the theme of scissors, where they take on the dynamics of a character set in motion on the paper. 


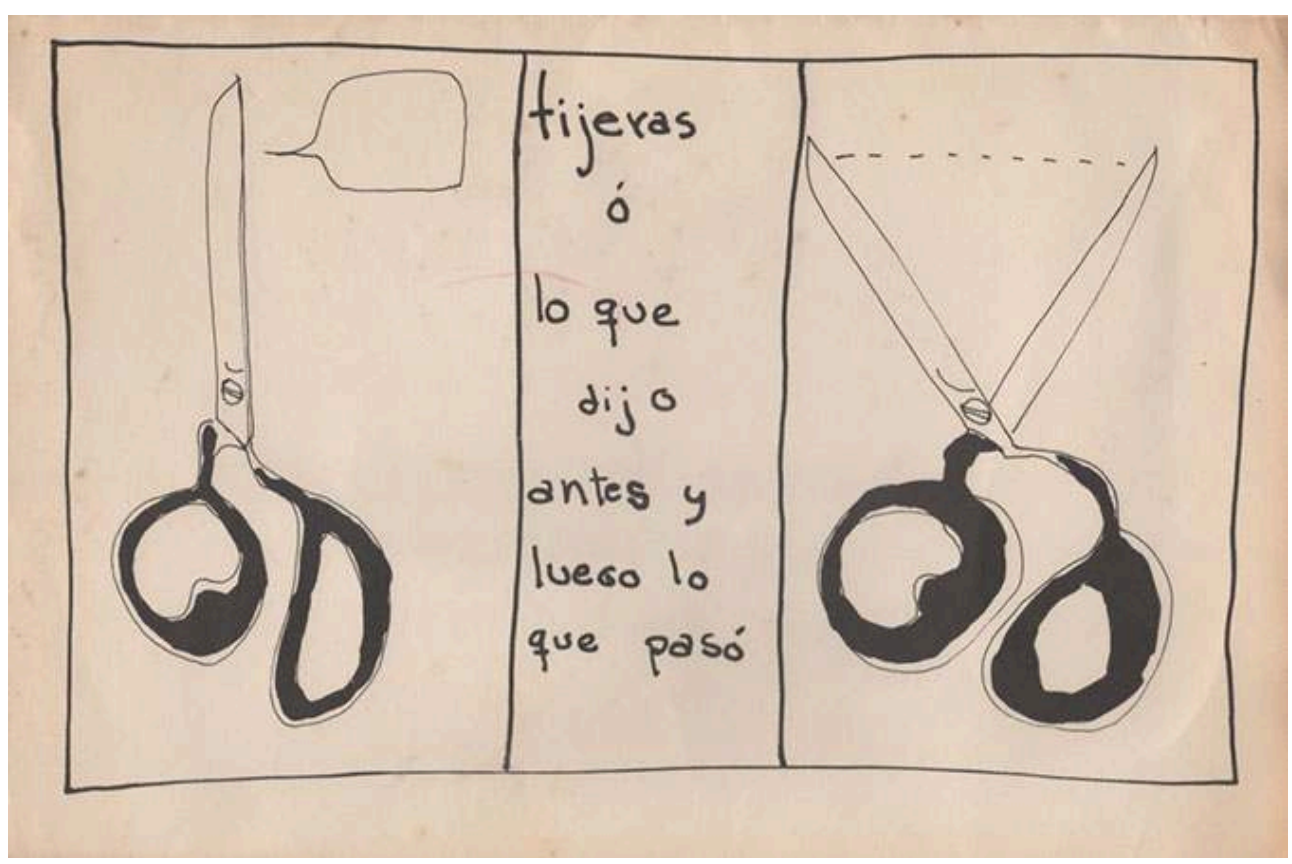

Even though comments in the press leave no evidence of the rejection, Magali Lara claims that this exhibition, presented at the Escuela Nacional de Artes Plásticas de Ciudad de México during 1977, generated adverse reactions (some people hated the show, there were friends who stopped talking to her ${ }^{7}$ ). Notwithstanding, the University incorporated some pieces into its collection. In the catalog text, art historian Juana Gutiérrez ${ }^{8}$ explained what a pair of scissors were by describing them and referring to verbs associated with the actions that could be carried out with them (tijereteada, tijeretear, tijereteo: variations of the word tijera (scissors), referring to the action of clipping or snipping, but also to malicious gossip). An object related to sewing and cooking, when put in motion on paper it became a "sharp-edged weapon" of humoristic sensuality. The rejection by the public would seem to have come from the violence inherent in the theme. The hierarchical positioning of a banal object tied to the feminine realm bore a relationship to the program that appeared in the North American line of feminism, ennunciated by women artists associated to The Woman's House in Los Angeles. This dealt with elaborating an iconography of everyday objects that Lara utilized as a point of departure for an autobiographical investigation in which she interleaved texts in which she defined herself as a middle class woman from the third world. In one sense, scissors and ventanas could be thought of as transitional objects, spaces or intermediate areas between her and reality or the outside world, between the subjective and the objective (WINNICOTT, 1971). The space determined by the frames in the Ventanas series served to superimpose images using transparent sheets of paper, reptitions of orthogonal structures, pictorial material, texts (from poetry, conversations and her own poetic writing) and photographs. Magali Lara did not identify with feminism because, as she sustained, more than lay out an agenda, she wanted to propose options or positions regarding the feminine.

When Pola Weiss ${ }^{9}$ showed her videos in the same Salón de Nuevas Tendencias, she had already presented her controversial final project to recieve her degree in Communications Science from the Political and Social Science Department at the 
UNAM, presented in video format. ${ }^{10}$ she had also made an incursion into state television. It began with a close-up image of a flower in the water. When the camera zoomed out, the complete shot revealed that the whirlpool maintaining the flower in its place was that of a toilet. The program was about the 1968 student movement, with invited guest Carlos Monsiváis. The ironic political allegory that Weiss presented did not appear to be exactly appropriate given the serious nature of the topic. This was her only incursion into state televisión (CARRASCO, 2000). Her interest in the camera and editing dated back to 1971, when she took a course at the Centro Universitario de Estudios Cinematográficos (CUEC-UNAM) and continued in 1974, when she traveled to Europe to carry out an investigation on artistic television at the BBC in England, the VPRO in Holland, the OFRATEME in France and the RAI in Italy. In 1976 she came into contact with video art in New York by way of videos by Nam June Paik. The following year, she applied the self-denomination of "teleartist" and created her ArTV company, with which she presented her idea of art on television. There were two videos by Weiss at the Salón Nuevas Tendencias, both centered on the women's relationship to the city.

Pola Weiss, Somos mujeres, video, 1978

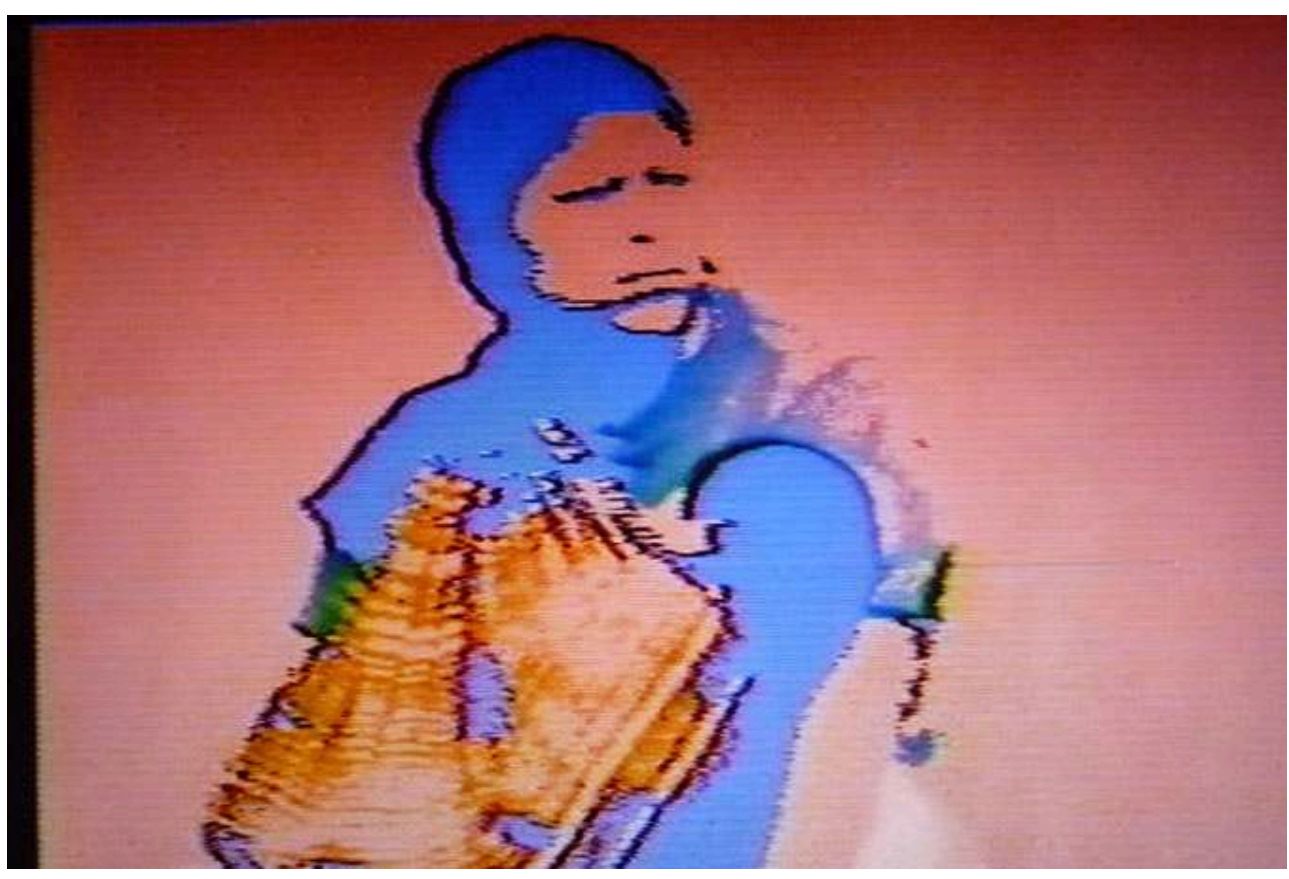

Fondo Pola Weiss-Edna Torres. Centro de Documentación Arkheia. Museo Universitario Arte Contemporáneo, UNAM

Somos mujeres(1978) is a piece by Pola Weiss with music by Carlos Guerrero, assistant Magda Hernandez and produced by ArTV. Duration: 6 minutes.

Somos mujeres is inscribed within a social register. The camera moves quickly between modern buildings like the Torre Latinoamericana (Latin American Tower) and women begging on its front steps, children in arms. Women's and children's weeping mixed into the soundtrack confirm the social message. Women's problems are above all issues of social class and race. These are poor indigenous women. The film emphasizes this by superimposing the voices and weeping of the images captured in documentary language. 


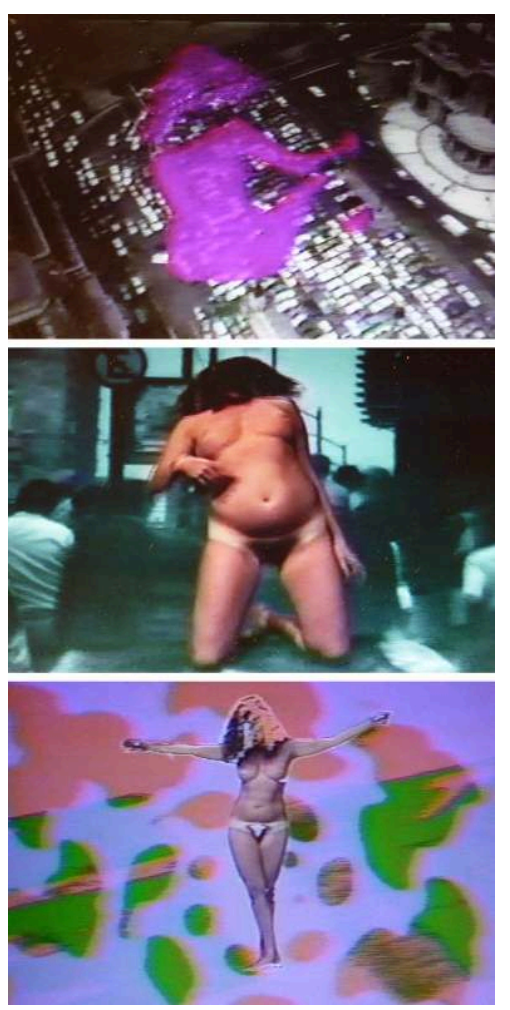

Fondo Pola Weiss-Edna Torres. Centro de Documentación Arkheia. Museo Universitario Arte Contemporáneo, UNAM

Mujer-ciudad-mujer is done on a different register. It involves Pop, psychodelia, nudes and contemporary dance: the images refer to young, middle-class women exposing their naked bodies which merge with images of the city (traffic, highways, the Palacio de Bellas Artes) by way of post-production techniques such as chroma key and solarization effects and editing. The original music is by her sister, Kitzia Weiss. The voice in off is that of Pola, who recites a text written by her about the relationship between a woman, water and city noises. Pola Weiss experiments with an audio-visual proposal that introduces precursory elements of what we now know as "video-dance". ${ }^{11}$ Not only her choice of themes is notable, but also the fact that she opts for the most advanced forms to express herself in a new technical medium. She explores video's possibilities as an autonomous language.

According to Jorge Carrasco V., the video was censored on commercial television because of the nudity. A body is seen frontally, with bikini lines, exposed breasts and tremulous movement of the pubis, culturally mediated by contemporary dance or corporal expression. This type of movement disrupted the rigid parameters and discipline of classical dance; it opened up a space and codes that were more accessible, capable of liberating the body. In many performances from the seventies, artists moved in leotards, but barefoot instead of using toeshoes. ${ }^{12}$ The movements of Weiss' model are undulating, ${ }^{13}$ repetitive and follow the rhythm of percussion, introducing an element of primitive liberation. The text refers to a tense relationship with the city. As a whole, it portrays a general existential search rather than a feminist political agenda such as that which can be recognized to a certain degree in Somos mujeres. This body disrupted the cultural mediation that classical themes had provided since the 
$19^{\text {th }}$ Century, and was naked in a contemporary format. It is a nude mediated by the culture of a young, middle class woman. Weiss compressed data in order to approach a reformulation of the body of a contemporary woman based on the rhythm of the visual impressions of the city. Her purpose was to activate the spectator. Video allowed her to awaken viewers with music, forms, dance and movement: "It is like a synthesis in which an idea that cinema would trasmit in two hours here is achieved in ten minutes" (CARRASCO, 2000).

The work that Mónica Mayer presented in Nuevas Tendencias took on the relationship between women and the city based on sociological material. She repeats the structure of lines used for drying clothes, that is, a clothesline, associated with domestic cleaning chores. Mayer preseted the results of a survey that she had carried out among women from Mexico City in the form of a sentence that had to be completed: "As a woman, what I hate the most about the city is ..."

Mónica Mayer, El tendero, instalación, 1978

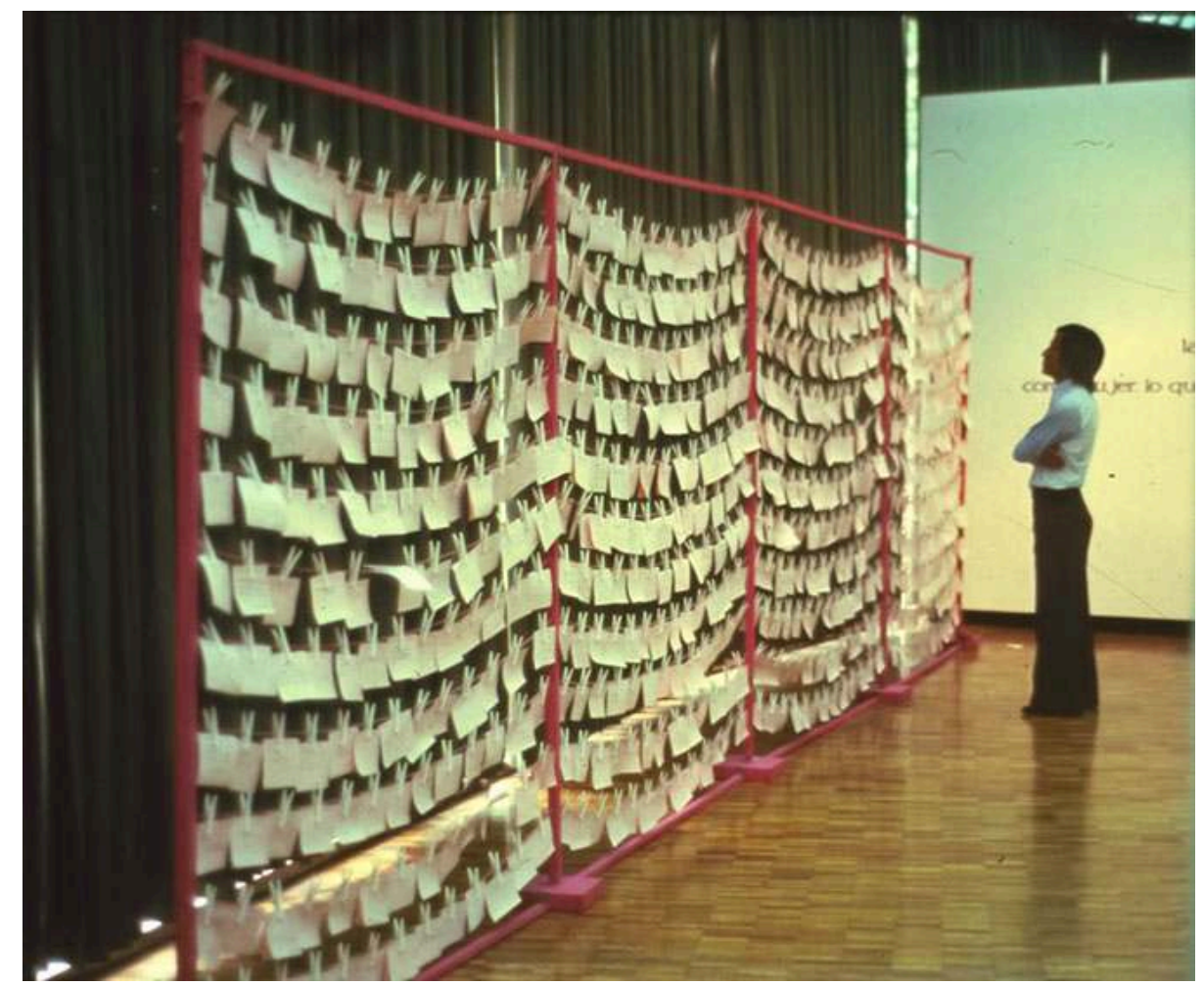

Salón 77-78 Nuevas tendencias, Museo de Arte Moderno, México D.F.

The clothesline was painted pink. The sheets of paper that included the responses collected from eight hundred women of different ages, professions and social classes that Mayer had consulted, hung from it. The majority referred to sexual violence in the street. Mayer investigated different ways of showing an archive of responses; she would open it for public participation in the exhibition space, inviting them to add new commentaries, thus acting out the hard data from a sociological report. The objectivity of the data collected was disrupted by the domestic format in which it was displayed. Mayer could have presented the results of her survey in a graphic format, but she chose the poetry of household order instead. The object of domination was subverted in order 
to back up a liberating collective message of protest. The domestic thus took a turn toward the political.

These three works introduced alternative responses to the questions that Stellweg had handled in her survey. Above all, regarding whether or not art by women had specific markings of its own. In one part of the exhibition hall, the works triangulated different forms of approaching the issue of women's place as it had emerged during preceding years. ${ }^{14}$ Pola Weiss showed a nude, non-idealized body shimmying to the rhythm of percussion with the tumultuous city as a backdrop, a city that also served as the framework for poor indigenous women begging in the street with their children. Magali Lara interevened as a middle-class woman from a psychological viewpoint, investigating her condition as a woman artist by way of biographical and subjective vectors. Mónica Mayer articulated the relationship between women and the city from a social perspective, enacted based on the documentary records of written responses. All these works were presented together, in an exhibition space with high visibility. Nevertheless, they were not perceived as formulations that had been articulated in relation to a theme that had convoked so many meetings and voices two years earlier.

\section{Translations: An International Dialogue of Women Artists}

38 The publication of the aforementioned issue of Artes Visuales had additional consequences. In its pages, Mónica Mayer would have the opportunity to become aware of the existence of the feminist education program in Los Angeles, read the interview with Judy Chicago, contact the artist, participate in a two-week workshop and decide that she wanted to participate in the program at The Woman's Building at the California Institute for the Arts. During the two years that followed while she was saving money for her studies, she joined the Movimiento Feminista Mexicano (Mexican Feminist Movement), part of the Coalición de Mujeres Feministas formed in 1976, which other groups would also soon join. ${ }^{15}$ Mayer participated in discussions at meetings that she describes as vigorous, radical marathons immersed in impenetrable cigarrette smoke (MAYER, 2004; p. 23). The main issues under debate were violence and abortion. At the same time, she began to undertake actions in the street: she would do so with her mother, who realized that the same repressive forces that had ended the lives of young people in Tlatelolco Square in '68 were ready to take action again.

Nevertheless, politics did not occupy an exclusive place in Monica's agenda. She wanted to merge political feminism and artistic feminism; she wanted to generate feminist art. ${ }^{16}$ Her experience in Mexico and what she had learned at the two-year course at the Feminist Studio Workshop during her formation at The Woman's Building in Los Angeles were key. A 'small group' methodology was used there, based on dialog on recurring issues in feminism related to relationships with money, love, the body and sexuality. The personal realm was amplified in the experiences of the members of the group and of society. Artists from the past were also studied in order to elaborate an alternative history of art that took the works of past women artists into account. Heterogeneous materials were utilized and performances dealing with issues such as incest or lesbianism were often called upon. These activities were mixed with classes on Marxism or Political Art. In 1980, she received a Master's Degree from Goddard College in Vermont, USA, with a thesis on her experience in Los Angeles titled Feminist Art: an 
Effective Political Tool. Her final project took the shape of an exhibition, or to be more precise, a trans-national experience that consisted of bringing three women artists with ties to The Woman's Building (Jo Goodwin, Denise Yarfits and Florence Rosen) to Mexico to give conferences and to participate in a group workshop with women from Cuernavaca. The experience was called Traducciones: un diálogo internacional de mujeres artistas (Translations: An International Dialogue of Women Artists). From Mexico, Lilia L. de Mayer (Mónica's mother), Ana Victoria Jiménez, Yan Castro, Mónica Kubli, Ester Zavala, Marcela Olabarrieta, Yolanda Andrade, Ana Cristina Zubilaga and Magali Lara all participated in the organization.

Translations: An International Dialogue of Women Artists, 1979, meeting at Mayer's mother's house, México D.F

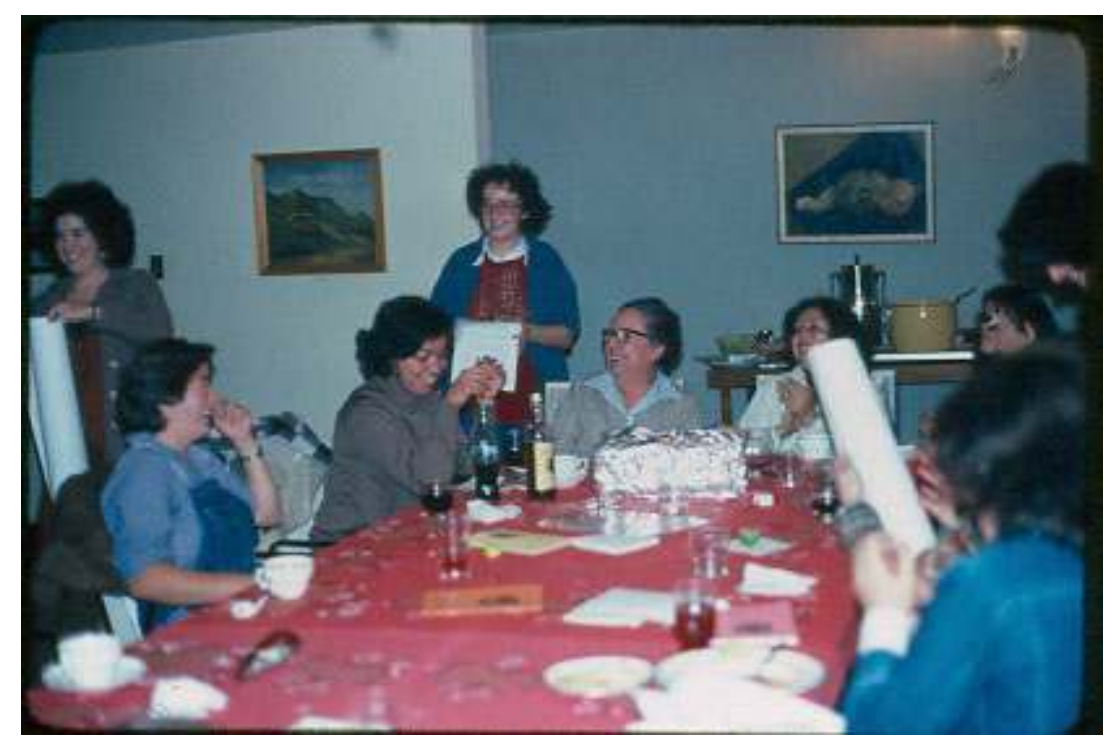

In the report preserved in Mónica Mayer's archive, different purposes are expressed: that of becoming familar with feminist artists from Mexico as well as developing a trans-border community based on new friendships. Books, posters and slides were brought from the United States to Mexico to be presented and shared during a two-day workshop and five audio-visual presentations.

They left on December 10, 1979, headed to Mexico City first. Her mother, representing the Movimiento Nacional de Mujeres (National Women's Movement), awaited them at the airport. They were welcomed with a Mexican breakfast and presents brought from the United States were given in return. The evening meals would begin at 8:00 pm and end at 1:00 in the morning. The day after their arrival they went to see the Virgen de Guadalupe, where there were around a million people, allegedly pre-Colombine dances, anti-abortion signs, Mexican food, colors and garments. They walked around, taking in all of Mexican culture's richness. They visited a Mexican artist's proletariat neighborhood in order to comprehend why the class struggle had so intensely permeated the feminist movement in Mexico. This political condition made dialog with Mexican women difficult, for whom North Americans were part of the imperialist regime. They also went to see a theater piece by Nancy Cárdenas, probably the first to be presented in Mexico that dealt with lesbianism.

The first slide presentation took place at the Museo Carrillo Gil, on the topic of the history of women in art from the 12th Century onward. Jo Goodwin was primarily in 
charge of the talk. Mayer carried out simultaneous translation and the public consisted of approximately 40 men and women. There they came into contact with art critic Alaide Foppa, who asked them for material for her radio program. That night, as they were eating tacos, they met Magali Lara. They also visted Frida Kahlo's house. In the evening, the second slide presentation, on contemporary women artists, took place for an audience of some 30 people who arrived late due to a demonstration by farmers that had cut off traffic.

On Saturday, they left for Cuernavaca, where they participated in a workshop attended by between 30 and 70 women (the title was Feminismo, Mujer y Arte (Feminism, Woman and Art). During the workshop, slide performances alternated with performances dealing with sexuality and the abuse of authority, involving intense emotions on the part of the participants.

Translations: An International Dialogue of Women Artists, 1979, workshop at Cuernavaca

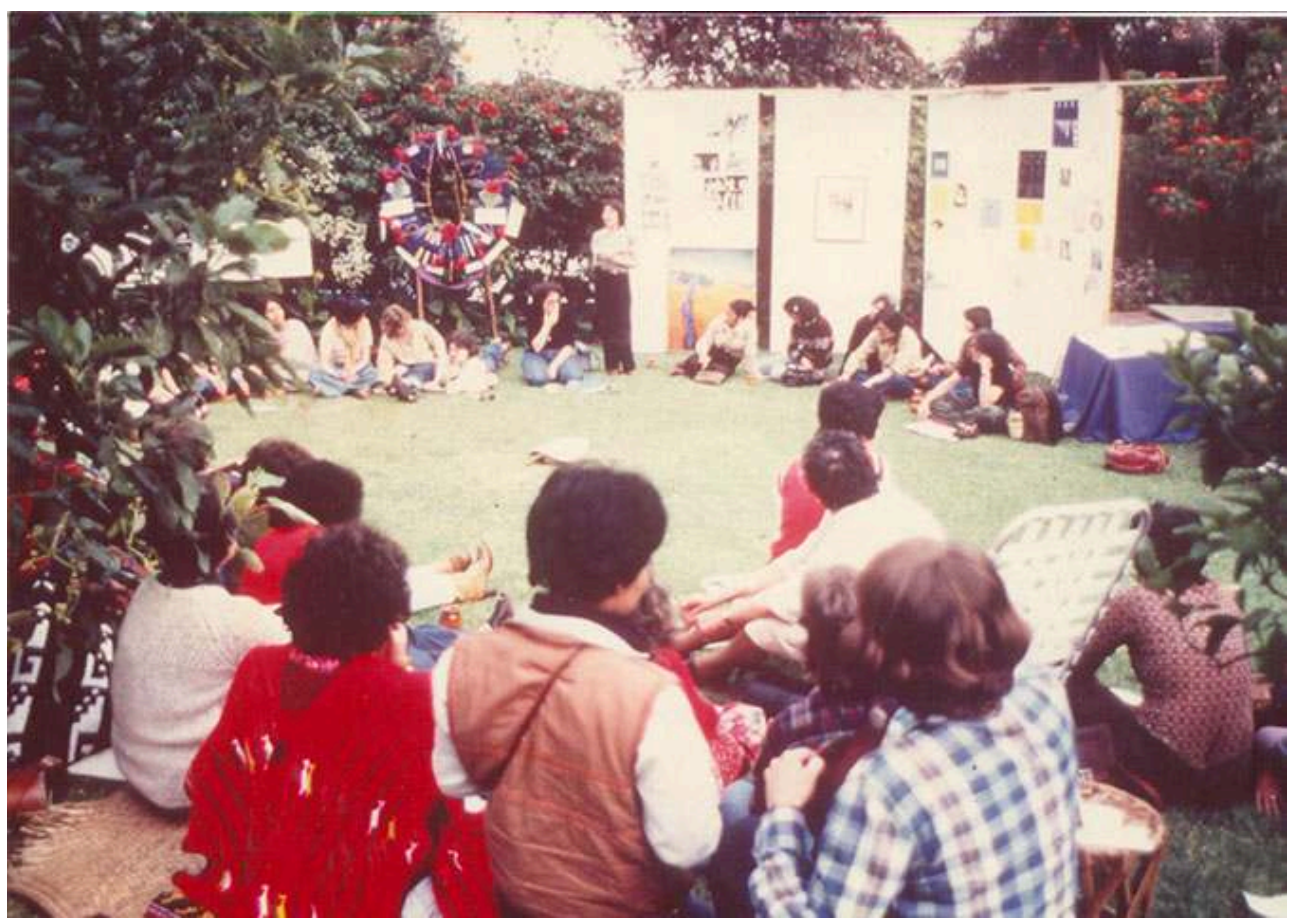

While some participated, others expressed their disagreement with these experimental activities on political grounds. The workshops brought together women from different backgrounds and they took place in an atmosphere of investigation, participation and conflicts. They ended with music, food and works presented by some of the participating Mexican artists (such as Ana Victoria Jiménez, who showed photographs from her book of narrative photography, Columpio sobre el precipicio (Swing on the Precipice, 1985). 


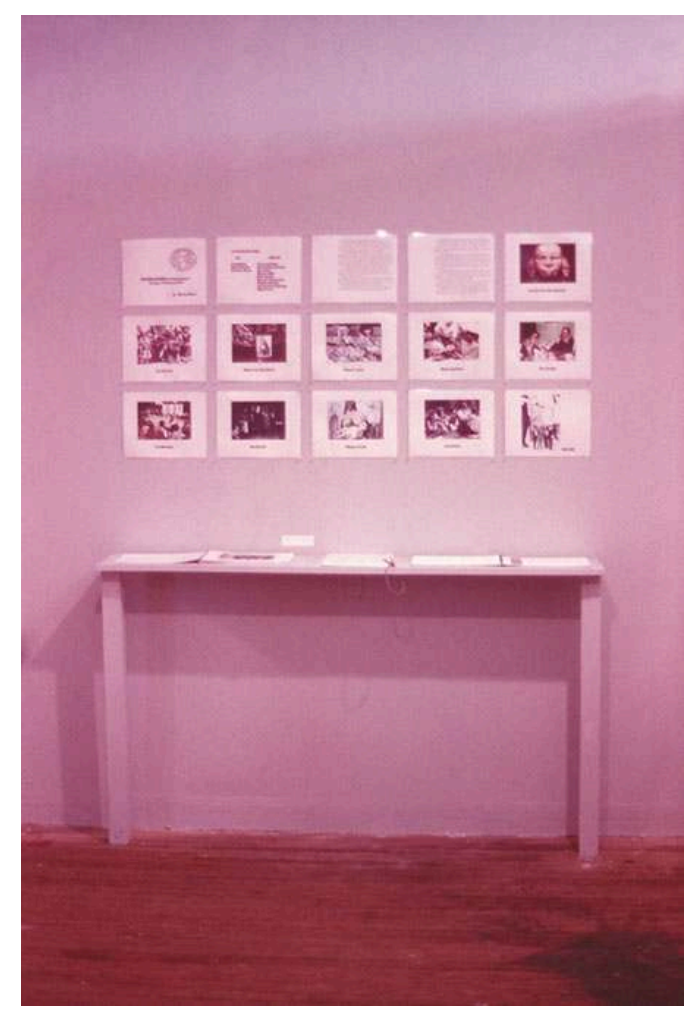

The results of the encounter were presented in March of the following year at The Woman's Building along with documentation of the event. The exhibition included images and a text about the exchange that had taken place in the form of a book, edited by Mónica Mayer (MAYER: 1980). The publication was presented as the script for an audio-visual piece, combining a body of images on traditional Pre-Hispanic Mexican goddesses, information on the situation of feminism in Mexico and its political interception, Mexican culture in general (celebrations and religious practices), women's roles in Mexican society, the significance of 15th birthday celebrations for young Mexican girls, women's relationship with the labor market, education and the dynamics of the meetings in Mexico City and Cuernavaca. The images were photocopied photographs, in color and laminated, shown on a mantel shelf with texts in English and Spanish.

I describe this experience in detail in order to restore its complexity and structure. I want to bring the reader one step closer to the events that brought a group of women of different nationalities together over the course of several days. The moments they shared were the result of a coordinated trip for research and exchange that required planning and resources. It involved bringing the feminist experiences of two countries into contact, dialog and confrontation. As a result it became clear that the language being used in Mexico was more political and sociological than that being used in California. At the same time, a transnational scenario for creative exchange between women was created, constituting a transitory community. The informative activities related to the history of art were not the only things shared during the days they spent together. They ate, walked around, went into markets and ruins and participated in celebrations. This involved a cultural learning experience that they lived and went through together. This dialog could be compared with today's workshops. It also 
anticipates micro-political community programs of dialog organized in relation to a common objective, where each person's sphere of pertinence is disrupted to immerse one's self in a time shared with others that transforms preconceived notions, perceptions and thus broadens knowledge through living with others.

One of the organizers in Mexico was Ana Victoria Jiménez. She did not originally come from an art background, but rather from experiences of feminist political activity and editorial projects. She began to put together an archive on feminism in Mexico in 1964, and today it includes over 3,000 analog photos and more than 500 documents. ${ }^{17}$ During the seventies she took a photography course and began to develop feminist photographic works. It was then that she produced her first photographic essay, published in 1985 (JIMENEZ: 1985). The text narrates the experience of an old woman who climbs up a tree and talks about her youth, the illusion of getting married and her dreams. Her husband beats her and she goes mad. Her children are taken away from her. The text evidences the influence that religion has in the life of a woman in a small village in Mexico. The images are a series of photographs about trees produced by Jiménez for the book. Between 1978 and 1980 she developed a second photographic essay about domestic labor.

Ana Victoria Jiménez, unitled, photographs, 1978

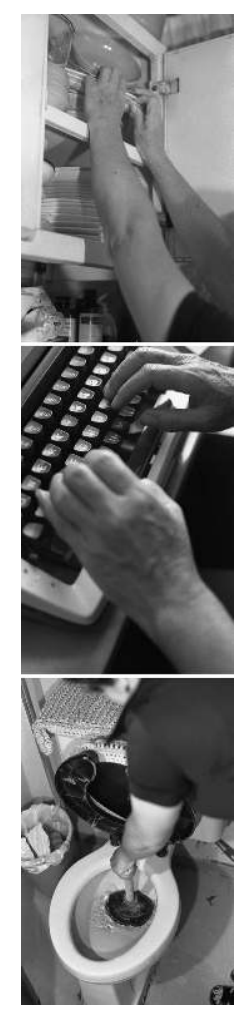

The series constructs an iconography of the hands and their relationship with objects that narrate domestic activities-cleaning the bathroom, washing dishes and clothes, cooking or writing-with close-ups of their details and texture, looking to leave a testimony of their corporal nature and intimacy. They register the physical nature of action and of the grandiloquence that the most common of objects, lacking hierarchy, achieve when put into motion by hands. They comprise a small domestic theater, a stage. The timeline of history does not incide in these photographs. They refer to 
actions and tasks that are recorded as if being catalogued. They are proof of the repertoire of objects from domestic chores.

\section{Mother for a day}

49 artists from the seventies and eighties, the body has a central, recurring place in them. ${ }^{18}$ The need to subvert patriarchal parameters for representing the body led artists to investigate it, dissect it, penetrate its substance in all of its orifices and fluids. The recurring forms that Judy Chicago or Lucy Lippard indentified as typical characteristics of a feminine sensibility were constants gathered from their view of what had been produced and they would lead to an investigation of new iconographies in the context of questions regarding women's place on a political plane. What became visible was not only fluids, genitals and secretions, but also an insistence on a political reading that considered the nude body to be the bearer of transformative power. These certainties underwent turbulence when humor was introduced. This allowed for an anticipation of critical aspects regarding stereotypical constructs of the female body that the search for a specific iconography actually contributed to in a certain way. Performance was the medium that best enabled these arguments to be expressed from that distance, primarily those carried out jointly by Maris Bustamante and Mónica Mayer. produced anti-rapist potions that they distributed in public. Popular culture became a strategy for critical interventions presented in the form of parody. This allowed them to introduce ambiguity in the very codes that give order to feminism's repertoire. This irony and taking certain distance act as much in relation to the world denounced by feminism (violence against women), as against the repertoires consolidated by feminism, and begin to constitute an analysis from the standpoint of post-feminist critique. This mechanism's most radical form may well have been achieved when this device allows them to dismantle the maternal figure. Even as feminism critically revised the maternal role, no questioning was raised regarding its sacred status nor its intimate, identifying and essential relationship with the female body. The historical conditions that would convert the certainties or the naturalization of a role into a cliché or stereotype did not yet exist. It is for this reason that I would like to emphasize that, in spite of focusing their performances during that era on maternity, while they were pregnant themselves, they inscribe it within an irreverent discourse. In the Madre por un día (Mother for a day) performance, carried out on Guillermo Ochoa's program Nuestro Mundo, ${ }^{19}$ they intervened the masculine body, and queerized maternity.

The performance's argument is structured according to the communicational logic of television as arbitrated by host Guillermo Ochoa, who directs the presentation by way of his questions. The accumulation of parodical elements (from Bustamante's childish, decorous tone to her rationalization of family planning, assimilated to a reproductive project tied to conceptual art) de-naturalize the canonic narrative of maternity. They explain that what they want to do is to introduce a feminine perspective of feminine themes that have been handled by men. "The thing is that maternity leaves little room for men", says Ochoa. As a result, Bustamante, who points out that at that moment television is like the Museum of Modern Art for them, announces that they are going to carry out an artistic event, turning him into "Mother for a Day". In order to do so, they 
pull their "instruments" out of a shopping cart: artificial bellies for each one, a box with powders and substances associated with pregnancy's symptoms (to produce cravings, fight against dizziness, protection against envy or evil eye) and a little book with objects to bring good luck, fortune and stimulus to learn new skills such as cooking.

Mónica Mayer and Maris Bustamante, Mother for a Day, at Nuestro Mundo, Guillermo Ochoa's television program, Televisa Channel 2, 1987

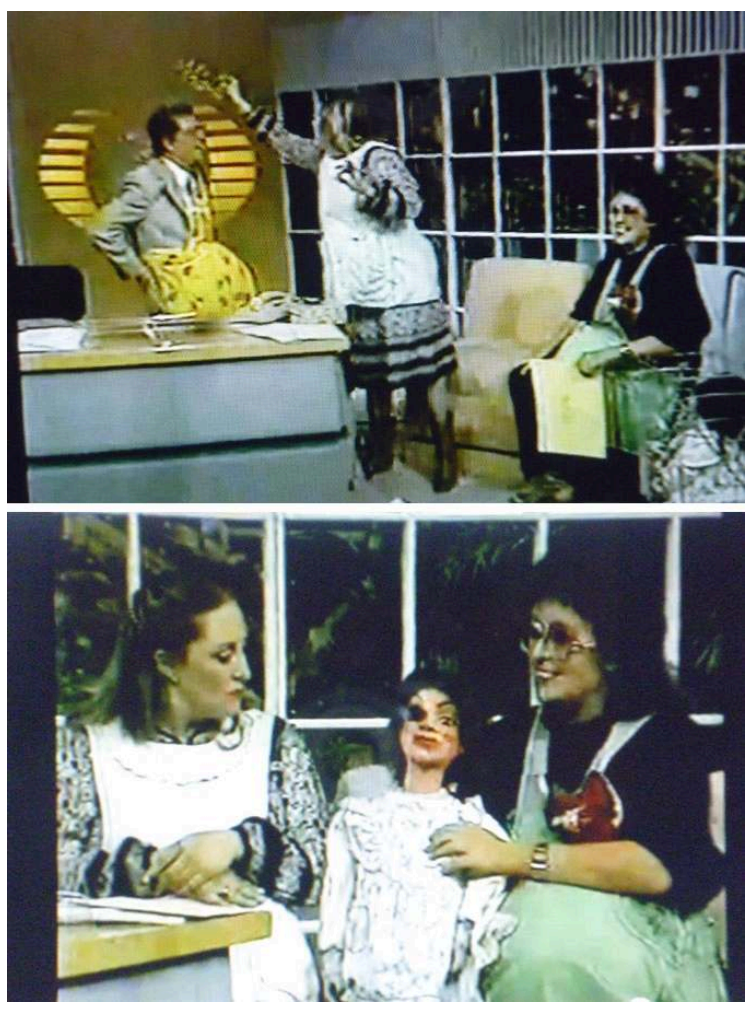

http://www.youtube.com/watch?v=WEhYebSmX2c\&feature=gv

They crown him and present him with a diploma. A doll with a patch over one eye sits between them, representing the malevolent mother, far from the pristine, idealized figure of the mother created by patriarchal discourse regarding the family. The mother-doll-little girl is Catalina Creel, the nasty mother character from the soap opera Cuna de lobos, ${ }^{20}$ a stereotypical evil woman made popular by the audience of this program. By way of all these elements they convert his masculine body into a mother's body, they mechanically overturn his genetic condition and convert it into a strange body, the other's body, a queer body. The humor and sarcasm of the performance not only allow them to dethrone maternity's beauty and naturalness, but also to separate it and take it apart from the female body in order to install it in a masculine body that could potentially be an other. Maternity, as well as sexuality, are deduced from this action; they are not natural, but cultural constructs. The laughter it provokes functions as a distancing mechanism, folowed by cultural reflection. Maternity is taken out of the niche defined by publicity and the feminine and is converted into a group of devices that disassemble the body. These devices utilize symbolic objects associated with the highly idealized natural condition that become merely pieces like cogs and wheels once subjected to a taxonomic, mechanical order of things. In its entirety, the performance entails a critique of the feminism that was dominant in visual expressions being 
elaborated from the sixties onward. It was not a question of merely creating an iconography that would represent women, their world and their sexuality; it was a matter of releasing this repertoire from the feminine body in order to convert it into a device for a genre constructed on the basis of options inaugurated by the very process of visualizing its construction. In this performance, they produce a de-naturalization, they introduce alternatives and resistance against the normative nature of gender. They activate a field theory, which Beatriz Preciado denominates "contrasexuality", understanding this to be like situating one's self outside of man/woman, masculine/ feminine oppositions. From this perspective, Preciado defines sexuality as "technology" and considers that "the different elements of the sex/gender system denominated 'man', 'woman', 'homosexual', 'heterosexual' or 'transexual' along with their sexual practices and identities are no more than machines, products, instruments, apparatus, tricks, protheses, networks, applications, programs, connections, flows of energy and information, interruptions and interruptors, keys, laws of circulation, borders, constraints, designs, forms of logic, teams, formats, accidents, detritus, mechanisms, uses, detours..." (PRECIADO: 2011, p. 14). At the end of the performance Ochoa takes off his prosthetic belly: "it really is good to be able to take it out when you want to", he confirms. He closes the segment by re-establishing roles: "Friends, after the following messages, this program's 'macho' will be back".

\section{Conclusion}

53 Taken as a whole, all these works add complexity to feminist discourse in Mexico following the rupture produced during the seventies, marked by the seminar compiled in Artes Visuales and including the development of languages and intervention strategies that were unparalleled in Latin America. This was not because the formation of artistic feminism was not being articulated in other places, but because they had to confront two scenarios that interrupted their progress: political militancy and coups d'état. This is what happened with the feminist groups that were organized in Buenos Aires, for example, who would only re-emerge during the eighties, after the return to democracy. The work of Colombian Clemencia Lucena (1945-1983) could be analyzed from a comparable angle. During the early seventies she was producing conceptual work that questioned the social stereotypes that dictated Colombian women's place, but as the decade advanced, her aesthetic became immersed in realist painting tied to Maoism, where women's role is defined as mother and comrade.

54 Although we have seen by way of the comparison between Mexican and North American feminism that the former was imbued with politics to a much greater extent, it was nevertheless not capable of interrupting its development. This allowed for the articulation of diverse strategies that produced an arena for investigating diverse languages (painting, installation, performance and video) and formats for exhibiting archives. These investigations involved an early critique of feminist stereotypes; they introduced elements that opened experiences to post-feminist readings by converting the feminine state par excellence-maternity-into a set of devices that could turn anyone into a mother for a day. Humor allowed them to generate distances that would lead them from feminism's set agenda to politics of the body. 


\section{BIBLIOGRAPHY}

ANA VICTORIA JIMÉNEZ. Columpio sobre el precipicio (narración fotográfica). Litografía Figueroa, Mexico City 1985.

ARACELI Barbosa. Arte feminista en los ochenta en México. Una perspectiva de género. Universidad Autónoma del estado de Morelos, Morelos, 2008.

CARRASCO V., Jorge. "Pola Weiss: la cineasta olvidada". en Etcétera. Política y cultura, 2000. http:// www.etcetera.com.mx/2000/399/jcv399.html (consulted on June 20,2013)

KAREN CORDERO Reiman and Inda SÁENZ (comp.). Crítica feminismta de arte en la teoría e historia del arte. Universidad Iberoamericana y Programa Universitario de Estudios de Género-UNAM, Mexico City, 2007.

DALLAL, Alberto. La danza en México en el siglo XX. México, Consejo Nacional para la Cultura y las Artes, Mexico City, 1994.

FERNÁNDEZ, Justino. Arte mexicano: De sus orígenes a nuestros días, Editorial Porrúa, Mexico City, 1961.

GROBET, Lourdes. Lourdes Grobet. Turner Publications, Spain 2005.

LIPPARD, Lucy. “¿Por qué separar el arte femenino?”. In Artes Visuales No 9, Revista del Museo de Arte Moderno, Mexico City, 1976.

MAYER, Mónica. Translations: An International Dialogue of Women Artists. Mayer, Mónica; Goodwin, Jo; Yarfitz, Denise, Los Angeles, 1980.

Rosa Chillante. Mujeres y performance en México. CONACULTA-FONCA, Mexico, 2004.

NOCHLIN, Linda. 'Why have there been no great women artists?', ARTnews 69, January, pp. 22-39, 67-71, New York, 1971.

PRECIADO, Beatriz. Manifiesto contrasexual, Anagrama (extended and corrected edition, 1st edition in French 2000), Barcelona 2011.

RANDALL, Margaret. To Change the World: My Years in Cuba. Rutgers University Press, Piscataway, NJ, 2009.

STELLWEG, Carla. "Mujeres/arte/femeneidad". Artes visuales No. 9, Museo de Arte Moderno, Mexico City, March, 1976, p. 5.

TORRES RAMOS, Edna. Pola Weiss, pionera del videoarte. Muestra homenaje. UNAM, Ciudad Universitaria, Mexico City, 1998.

WEISS, Pola. "Reflexiones sobre la situación actual de la mujer". mimeograph, San Bartolo Ameyalco, July 17, 1975, 4 pages.

WINNICOTT, Donald Woods. Playing and Reality. Tavistock, Londo, 1971.

JÁCOME, Cristóbal Andrés. "When Women Take Position. The Women Workshop at the Museo de Arte Moderno in 1975". Seminar by Andrea Giunta, "Radical Women in Latin American Art", Universidad of Texas at Austin, Fall, 2012. 


\section{NOTES}

1. Although works by Frida Kahlo, Leonora Carrington, Marysole Worner Baz, María Lagunes and Geles Cabrera were also shown (MAYER, 2004 : p. 20).

2. This publication is attributed with being the first on contemporary art published in Spanish and English in Latin America.

3. María Eugenia Stavenhagen (antropologist), Eugenia Hoffs (psychologist), Sara Chazán (lawyer), Margaret Randall (poet), Ida Rodríguez Prampolini (art historian), Teresa del Conde (psychologist and art historian), Rita Eder (art historian), Alaide Foppa (art crític), Berta Taracena (art crític), Helen Escobedo (sculptor and Director of the Museo de Arte Moderno), Angela Gurría (sculptor), Paulina Lavista (photographer), Myra Landau (painter), Fiona Alexander (painter) and Antonia Guerrero (painter) participated in the seminar, along with observers such as painter Cordelia Urueta or Emma Cecilia García, Carla Stellweg's assistant. Cristóbal Andrés Jácome made a preliminary analysis of this edition in the monographic work he presented in the seminar I held at the University of Texas at Austin, "Radical Women in Latin American Art", Fall, 2012 (JACOME, 2012).

4. Although Chazán did not detail the edition's exact title and year, she points out that it was from the sixties. It is probable that she was referring to the Porrúa edition (FERNANDEZ: 1961).

5. Randall was involved in Cuba's revolutionary process, to which she refers in her published memoirs (RANDALL: 2009). She lived in Cuba from 1969 to 1980. All this explains why she exemplifies women's role as educators, based on the Cuban experience instead of taking the situation in Mexico as her example. In addition to agriculture, education has been one of the areas of labor in which women have been most outstanding in Mexico from 1921 onward. However, being a revolution that emerged during the seventies, the Cuban revolution occupied a paradigmatic place that was in many cases exclusive in terms of delineating the history of modern revolutions in Latin America.

6. From 1974 to 1976 its Director was poet and academic Hugo Gutiérrez Vega, who was also President of the Comité de Apoyo a la Unidad Popular in Chile during the '70s, the leftist coalition that brought Salvador Allende into power.

7. Magali Lara tells of different ways in which the exhibition was rejected in the presentation she made to the Permanent Seminar at the Center for Latin American Visual Studies, University of Texas at Austin, on September 24, 2010.

8. Juana Gutierrez (1948-2007), Art History professor at UNAM, specialist in 17th and 18th Century art in Mexico, also educated a generation of historians in curatorial practice.

9. Regarding Pola Weiss's work, see Rita Eder's essay “El cuerpo y el espejo: ansiedades en la autopresentación", presented at the Sitac Meeting VIII Blind Spots, Puntos Ciegos in 2010. See: http://www.museodemujeres.com/matriz/biblioteca/023_ederita.html (19-07-2013)

10. My thanks to Edna Torres, specialist in Weiss' work, for facilitating access to videos, documents and an interview that were of great use in elaborating this text.

11. My thanks to Sebastián Vidal for his collaboration in analyzing the most innovative elements of this piece.

12. Faith Wilding and Janice Lester come to mind for their performance on masculine and feminine roles, Cock and Cunt, written by Judy Chicago and recorded in the film Womanhouse, or in the performance carried out by uruguaya Nelbia Romero in Republica de Montevideo square in the 80s. The figure of Texas-born Waldeen von Falkenstein (1913-1993), who dances for the first time in Mexico in 1934, is an essential one in relation to modern dance and these forms of bodily expression in Mexico. In 1939, the Secretaría de Educación Pública put her in charge of founding a company to develop modern dance. Her group began to hold presentations during the forties, giving rise to Mexican modern dance (DALLAL: 1994). 
13. Jorge Carrasco V. quotes the testimony of Salvador Huelgas, his head engineer at the Taller Experimental de Video at the FCPyS at the UNAM, when he recalls the alternatives involved in the shooting. "Pola had to find a model who was willing to appear nude, which was not a simple matter in that era. Someone gave her a famous model's phone number, but she misdialed and Vivian answered, and although she was not famous, she was an aspiring model, capable of anything'. (CARRASCO)

14. Mónica Mayer remembers that Pola Weiss' and Magali Lara's works were across from her installation. Interview with the artist, Mexico City, January 24, 2012.

15. In the feminism articulated in Mexico during the seventies, there were two primary groups : the Coalición de Mujeres Feministas, made up of six different groups that, in spite of differentiated political agendas, shared two fundamental points : 1 . Legalization of abortion and 2.opposition to violence against women (rape and battery). The second group was the Frente Nacional de la Liberación y Derechos de la Mujer, a national feminist organization. There were also cinema groups, which Mayer was a member of such as the Colectivo Cine Mujer by Rosa Marta Fernández, with whom she participated in the film on rape, Rompiendo el silencio (Breaking the Silence). Ana Victoria Jiménez also participated in this project (MAYER: 2004, pp. 21-22).

16. Mónica Mayer proposes the following differences: "Arte about women" is that whose theme refers to women, whether produced by women or by men; "feminine art" is that associated with certain aesthetic categories that traditionally characterize women as fragile and delicate (although she recognizes that these traits can also be found in art made by men); "feminist art", is that in which the artist assumes a feminist position and defends this position in ideological terms as well as in artistic terms ; and "gender art", is that made by artists who are influenced by feminist proposals although they do not assume a role as feminists or even reject the term (MAYER, 2004 : p. 24).

17. The archive is found in the care of the Biblioteca Francisco Xavier Clavijero at the Universidad Iberoamericana in Mexico City.

18. See, for example, the catalog for the exhibition WACK! Art and the Feminist Revolution, held at the Museum of Contemporary Art in Los Angeles during 2007.

19. See: http://www.youtube.com/watch? $=$ WEhYebSmX2c\&feature $=g v$ (consulted on June 25, 2013). The program was aired on Televisa's channel 2 on August 28, 1987. The title and the performance appear to be a parodic allusion to the American television game show Queen for a day (1956-1964), where participants would present their financial and/or emotional situation in order to justify their need for the prizes offered. The winner was decided according to an applause meter, and would be draped with a velvet robe and given a crown and roses, converted into "queen" for a day. I thank Tamara Stuby for this reference.

20. The mother who commits murder to preserve the value of the family caste in the soap opera transmitted by Televisa in 1986 and 1987.

\section{ABSTRACTS}

Between 1975 and 1987 feminism in the arts in Mexico delineated a unique situation, one without parallel in the panorama of Latin American art. In a group of exhibitions, works and texts, women's place in Mexican art was critically analyzed, unfolding a broad map of positions. Although a chronology and list of names of the artists who shaped this scenario have been established, the intervention that each work proposed in the debate on women's place and the 
feminine that gained visibility during those years has not yet been examined. Based on a situated analysis of these works, this article proposes to discuss these works' intervention in configuring how the debate on artistic feminism took shape during this period in Mexico.

Entre 1975 y 1987 el feminismo en las artes en México delineó una situación única, una sin paralelos en el panorama de las artes en América Latina. En una exhibición colectiva, tanto en las obras como en los textos, se analizó críticamente el lugar de las mujeres en el arte mexicano, con lo que se desplegó un mapa muy vasto de posiciones políticas. Aunque se han establecido tanto una cronología como listas de autoras que ayudaron a dar forma a esta posición, no se han examinado con cuidado las intervenciones particulares propuestas por obras individuales en el debate sobre el lugar de las mujeres y de "lo femenino" que adquirió visibilidad durante esos años. Basado en un análisis situado de estas obras, este artículo propone discutirlas como intervenciones que configuraron cómo tomo forma el debate del feminismo artístico en ese período en México.

INDEX

Keywords: Mexican art, feminism, women artists, Latin American Art

Palabras claves: Arte mexicano, feminismo, mujeres artistas, arte latinoamericano

\section{AUTHORS}

\section{ANDREA GIUNTA}

CONICET / Universidad of Texas at Austin Chair in Latin American Art History and Criticism, founder Director of the Center for Latin American Visual Studies, Department of Art and Art History, University of Texas at Austin, researcher of CONICET, Buenos Aires, recipient of the Guggenheim Fellowship, and author of "Avant-Garde, Internationalism and Politics: Argentine art in the sixties", Duke University Press, 2007. She received her PhD from the University of Buenos Aires. 